\title{
Understanding the Needs of Incoming College Freshmen: The Parent Perspective
}

\author{
Paige Harris ${ }^{1}$ and Heidi Liss Radunovich ${ }^{2}$ \\ College of Liberal Arts ${ }^{l}$ and Sciences, College of Agricultural and Life Sciences', University of Florida
}

Faculty mentor: Heidi Liss Radunovich, Department of Family, Youth, and Community Sciences

\begin{abstract}
In the last few years, there has been an increase in reported difficulties related to adjusting to college. While work has been done to analyze how college students perceive themselves related to several domains, such as mental health and physical fitness, there is little research to examine parental perception of college student functioning during the transition into college. Furthermore, there is reason to believe that students may differ in their perceived readiness for college based on their gender and socioeconomic status (SES). Using an anonymous survey, this study examined the extent to which 714 parents of students at a large, public institution in the Southeast perceived their college student as being prepared for university life on the domains of time management, social and emotional functioning, and general life skills. Oneway between-groups ANOVA analyses were conducted to determine group differences. Overall, significant differences by gender were found, with female students outscoring their male peers in many areas, as reported by their parents. Surprisingly, very few significant differences were found based on SES. Where there were differences, the low SES group outperformed their high SES counterparts. As universities consider the needs of incoming students, they may wish to be more intentional with how they target specific populations.
\end{abstract}

\section{Introduction}

In recent years, there has been an increase in reported difficulties related to adjustment to college (Conley et al., 2014). In some instances, these difficulties have been associated with mental health and coping skills (Durand-Bush et al., 2015; Leedy \& Smith, 2012), but in other instances these issues have been related to a lack of knowledge of life skills, such as how to select nutritional foods to eat (Holden et al., 2014). While there have been a number of studies that have compared how college students of different genders perceive themselves related to mental health (Dias \& Sá, 2014), motivation (D’Lima et al., 2014), and physical activity (Deforche et al., 2015), parent perception of these issues has been examined in a much more limited scope. It 
has been shown that high parent expectations of students ages eleven to sixteen positively influence student academic performance (Bornholt \& Goodnow, 1999). In addition, it has been shown that students whose mothers had higher expectations reported higher self-expectations as well as better self-concept of ability in an academic setting (Benner \& Mistry, 2007). Self-reported information is useful; however, it is possible that those students who are reporting might lack awareness of their areas of weakness, or may not want to admit their shortcomings.

In addition to gaps in the literature related to student adjustment and life skills, as well as parent perception of student functioning, it is also unclear whether differences exist related to student gender or family income. Despite current progress in reaching gender equality, young men and women are still bombarded by issues surrounding gender roles. Therefore, it is possible that there will be differences in student functioning or how parents view their children's functioning, especially in domestic activities such as preparing meals. Further, there is relatively little information available about the role that family income might play on students' life skills and coping skills upon entry to the university (Solis \& Durband, 2015).With respect to socioeconomic status (SES), there is an expectation of differences in student functioning related to domestic activities and independence. Children of low SES backgrounds are generally expected to take a more active role in housework and general life tasks, while higher-earning families tend to have access to housekeeping services and may not need their children to keep up the house (Klein, Graesch, \& Izquierdo, 2009). Furthermore, people of a lower-SES group are more likely to adhere to more traditional gender roles, while people of higher SES backgrounds are more likely to express egalitarian gender role attitudes (Marks, Lam, \& McHale, 2009). It has also been shown that people from a low-SES background can show a decreased "moral agency," resulting in potentially negative choices (Blacksher, 2002). This may lead higher-SES parents to ensure all life skills are practiced by all their children, regardless of gender. Given the exploratory nature of this study, it was expected that there would be differences found related to gender and family SES, however, it was unclear how the variables might differ.

Hypotheses for this study were as follows:

1. Parental perception of freshman students' emotional and life skill functioning should vary based on gender.

2. Parental perception of freshman students' emotional and life skill functioning should vary based on family SES. 


\section{Methods}

\section{Survey}

A survey was developed to delve into college student life skill functioning and coping using 30 items, and was embedded in a larger survey being administered by the Dean of Students' Office, for a total of 76 items administered. Information about the following life skills was assessed: money management, food management and safety, ability to keep self and home clean, time management, stress management, study and academic skills, knowledge of pregnancy prevention, knowledge of safety and ability to handle emergencies, handling social problems and situations, how to stay healthy, and ability to use campus resources. Parents were asked to report on their child's skill functioning level upon entry to the university as a freshman. Items were ranked by parents using a scale of 1 (unable to function) to 5 (able to fully function as an adult in this skill). Additionally, survey items that related to student gender and family SES from the larger survey were used for analyses.

\section{Participants}

While 830 parents agreed to participate, only 714 parents completed all measures. The parents were presented with 30 questions focused on several topic areas relating to life skills. They were asked to recall how they perceived their children as they began their first year of college, then they were asked to rank their child's competency in these areas on a scale of 1 to 5 , with 1 being the lowest perceived competency and 5 being the highest. The gender of target students was fairly evenly split, with $49.86 \%$ reporting on female students and $48.6 \%$ reporting on male students (the remainder indicated transitioning or prefer not to answer). Family income, assessed using an ordinal measure, ranged from less than $\$ 25,000(2.9 \%)$ to $\$ 150,000$ or more $(22.22 \%)$. For the purposes of this study, the lowest two SES groups (families earning $\$ 50,000$ or less) were compared to the highest SES group (families earning $\$ 150,000$ or more), essentially creating two groups representing low and high SES. There have been other studies that have used the $\$ 50,000$ mark as a cutoff point; one example can be seen in the work of Krishnan, S., Cozier, Y. C., Rosenberg, L., \& Palmer, J. R. (2010). 


\section{Procedures}

This study was conducted using an existing data set that had no identifiers. Data utilized had previously been collected in collaboration with this institution's Dean of Students Office after IRB approval, and was considered an exempt study. The Dean of Students office sent an email inviting participation in the survey to all parents on their voluntary Listserv, which comprised over 10,000 parents. The Campus Labs platform was used to provide the survey to ensure participant confidentiality. Participants were given a unique link to participate in the study in order for follow-up survey reminders to be sent to those who had not yet participated. The survey remained open for approximately one month, and up to three survey reminders were sent out to those who had not yet participated. This study utilized ANOVA to compare students by gender or income group on each item.

\section{Results}

The first hypothesis stated that parental perception of freshman student functioning would differ based on gender. A one-way between-groups ANOVA analysis indicated that a high number of items were significantly different based on gender. The only non-significant items were those related to financial matters, navigating social problems (such as talking to a professor or handling conflict), and personal safety. All other topic areas showed significant differences. See Table 1 for information about the mean, standard deviation, and significance level of each item.

The second hypothesis stated that parental perception of freshman student functioning would differ by socioeconomic status. One-way between-groups ANOVA analyses indicated that very few topic areas show a significant difference by SES; in fact, only two of the thirty questions yielded significant differences. These two questions were on 'keeping the home clean' ( $F$ $[288]=3.083, p<.01)$ and 'talking to an academic advisor' $(F[288]=1.441, p<.05)$. With regards to the item on keeping the home clean, the lower SES group had a mean of 4.16 and the higher SES group showed a mean of 3.79. The item on talking to an academic advisor showed a mean of 4.43 for the lowest SES group and 4.12 for the highest SES group.

Table 1. Gender means 


\begin{tabular}{|c|c|c|}
\hline Ability to manage stress & $3.77(.935)$ & $3.86(.949)$ \\
\hline $\begin{array}{l}\text { Knowledge of credit cards, loans, } \\
\text { savings }\end{array}$ & $3.86(.930)$ & $3.88(.974)$ \\
\hline Initiating a peer group & $4.04(1.035)$ & $3.86(1.168)$ \\
\hline $\begin{array}{l}\text { Ability to cope with failure and } \\
\text { challenges* }\end{array}$ & $4.04(.874)$ & $3.89(986)$ \\
\hline Keeping home clean*** & $4.08(.929)$ & $3.75(.983)$ \\
\hline Ability to self-advocate & $4.08(.949)$ & $3.96(.955)$ \\
\hline Comfort talking to professor & $4.13(1.011)$ & $4.00(1.118)$ \\
\hline Ability to use campus resources*** & $4.16(.895)$ & $3.90(1.089)$ \\
\hline Ability to manage money & $4.16(.850)$ & $4.06(.923)$ \\
\hline $\begin{array}{l}\text { Ability to handle academic } \\
\text { problems* }\end{array}$ & $4.20(.865)$ & $4.06(.965)$ \\
\hline Ability to handle conflict & $4.21(.794)$ & $4.22(.810)$ \\
\hline $\begin{array}{l}\text { Shopping for and preparing } \\
\text { meals*** }\end{array}$ & $4.21(.920)$ & $3.96(.921)$ \\
\hline Ability to handle social problems & $4.22(.793)$ & $4.24(.822)$ \\
\hline How and when to seek medical care & $4.26(.811)$ & $4.15(.719)$ \\
\hline $\begin{array}{l}\text { When and how to talk to an } \\
\text { academic advisor** }\end{array}$ & $4.28(.937)$ & $4.08(1.019)$ \\
\hline $\begin{array}{l}\text { Knowledge of strategies to stay } \\
\text { healthy** }\end{array}$ & $4.33(.731)$ & $4.15(.783)$ \\
\hline Joining a club or organization*** & $4.35(.930)$ & $4.10(1.107)$ \\
\hline $\begin{array}{l}\text { Knowledge what to do in an } \\
\text { emergency }\end{array}$ & $4.35(.745)$ & $4.36(.660)$ \\
\hline Nutrition and healthy eating* & $4.36(.871)$ & $4.20(.876)$ \\
\hline $\begin{array}{l}\text { Knowledge of safety in and out } \\
\text { of home }\end{array}$ & $4.41(.749)$ & $4.43(.712)$ \\
\hline
\end{tabular}




\begin{tabular}{lll} 
Ability to schedule time well*** & $4.41(.813)$ & $4.16(1.000)$ \\
Ability to study effectively*** & $4.45(.816)$ & $4.18(1.021)$ \\
$\begin{array}{l}\text { Working with people different } \\
\text { from self* }\end{array}$ & $4.46(.755)$ & $4.32(.833)$ \\
Ability to use public transportation & $4.46(.777)$ & $4.52(.801)$ \\
Food safety*** & $4.52(.742)$ & $4.31(.805)$ \\
Ability to write papers well*** & $4.61(.672)$ & $4.41(.816)$ \\
Arriving appointments on time** & $4.64(.672)$ & $4.47(.811)$ \\
$\begin{array}{l}\text { Ability to meet deadlines } \\
\text { independently** }\end{array}$ & $4.71(.661)$ & $4.51(.814)$ \\
Personal hygiene*** & $4.74(.599)$ & $4.78(.542)$ \\
\hline $\begin{array}{l}\text { Knowledge of pregnancy } \\
\text { prevention }\end{array}$ & $4.85(.427)$ &
\end{tabular}

Note: The varying significance levels are denoted by the symbol *. Significance at the 0.05 level is marked by a single asterisk, at the 0.01 level by two asterisks, and at the 0.001 level with three asterisks.

Table 2. SES means

\begin{tabular}{lcc}
\hline Topic Area & Low Income Mean (St. Dev.) & High Income Mean (St. Dev.) \\
\hline Ability to manage stress & $3.68(1.090)$ & $3.81(.951)$ \\
$\begin{array}{l}\text { Knowledge of credit cards, loans, } \\
\text { savings }\end{array}$ & $3.92(1.067)$ & $3.85(.967)$ \\
$\begin{array}{l}\text { Initiating a peer group } \\
\begin{array}{l}\text { Ability to cope with failure and } \\
\text { challenges }\end{array}\end{array}$ & $3.75(1.236)$ & $4.03(1.046)$ \\
$\begin{array}{l}\text { Keeping home clean** } \\
\text { Ability to self-advocate }\end{array}$ & $3.77(1.151)$ & $3.95(.915)$ \\
Comfort talking to professor & $4.16(.787)$ & $3.79(1.001)$ \\
& $4.14(.913)$ & $3.96(.997)$
\end{tabular}




\begin{tabular}{|c|c|c|}
\hline Ability to use campus resources & $4.06(1.084)$ & $3.99(1.018)$ \\
\hline Ability to manage money & $4.13(.934)$ & $4.03(.940)$ \\
\hline $\begin{array}{l}\text { Ability to handle academic prob- } \\
\text { lems }\end{array}$ & $4.19(.931)$ & $4.04(.967)$ \\
\hline Ability to handle conflict & $4.11(.925)$ & $4.17(.859)$ \\
\hline Shopping for and preparing meals & $4.00(.983)$ & $3.97(.968)$ \\
\hline Ability to handle social problems & $4.16(.865)$ & $4.22(.866)$ \\
\hline How and when to seek medical care & $4.27(.718)$ & $4.17(.781)$ \\
\hline $\begin{array}{l}\text { When and how to talk to an } \\
\text { academic advisor* }\end{array}$ & $4.43(.856)$ & $4.12(1.031)$ \\
\hline $\begin{array}{l}\text { Knowledge of strategies to stay } \\
\text { healthy }\end{array}$ & $4.27(.782)$ & $4.18(.771)$ \\
\hline Joining a club or organization & $4.08(1.182)$ & $4.31(.909)$ \\
\hline $\begin{array}{l}\text { Knowledge what to do in an } \\
\text { emergency }\end{array}$ & $4.35(.812)$ & $4.33(.722)$ \\
\hline Nutrition and healthy eating & $4.36(.932)$ & $4.23(.927)$ \\
\hline $\begin{array}{l}\text { Knowledge of safety in and out } \\
\text { of home }\end{array}$ & $4.43(.875)$ & $4.36(.758)$ \\
\hline Ability to schedule time well & $4.32(.947)$ & $4.19(.980)$ \\
\hline Ability to study effectively & $4.35(.970)$ & $4.23(1.017)$ \\
\hline $\begin{array}{l}\text { Working with people different } \\
\text { from self }\end{array}$ & $4.25(.891)$ & $4.40(.851)$ \\
\hline Ability to use public transportation & $4.48(.895)$ & $4.42(.862)$ \\
\hline Food safety & $4.31(1.001)$ & $4.32(.838)$ \\
\hline Ability to write papers well & $4.60(.778)$ & $4.46(.804)$ \\
\hline Arriving appointments on time & $4.57(.777)$ & $4.50(.830)$ \\
\hline
\end{tabular}




$\begin{array}{lcc}\begin{array}{l}\text { Ability to meet deadlines } \\ \text { independently }\end{array} & 4.54(.839) & 4.51(.810) \\ & & 4.54(.759) \\ \text { Personal hygiene } & 4.63(.701) & 4.78(.544) \\ \begin{array}{l}\text { Knowledge of pregnancy } \\ \text { prevention }\end{array} & 4.74(.575) & \end{array}$

Note: The varying significance levels are denoted by the symbol *. Significance at the 0.05 level is marked by a single asterisk, at the 0.01 level by two asterisks, and at the 0.001 level with three asterisks.

\section{Discussion}

It was hypothesized that the parental perception of freshmen student functioning would differ by the student gender. When examining perceived differences in life skills, the results suggest that there are significant differences between men and women in life skill functioning upon entry to college. Freshmen women generally performed better at the various life skills than men, as perceived by their parents. In every instance of significant difference, the females were perceived as functioning at a higher level than the males.

Some studies have shown that there are, in fact, neurobiological differences between the two sexes. For example, a study has demonstrated that the female brain reaches its peak size before the male brain in nearly every region (Ellison \& Nelson, 2009). This supports a theory that women mature more quickly than men, and their performance on life skills is related to gender differences in neurological development. Another potential contributor to differences is gender roles. Gender roles potentially placed on these students by their parents and society as a whole could also affect how the student is perceived as functioning these life skills. For example, women are often viewed as more likely to engage in domestic activities, and are often viewed as more emotionally intelligent by their coworkers and supervisors at work (Jorfi, Bin Yacco, \& Shah, 2012). Therefore, it is possible that parents simply assume that their children perform based on gender, but it is also possible that there have been family and societal pressures that have encouraged gender-based performance in these areas.

It was also hypothesized that the parental perception of freshmen student functioning would differ by the socioeconomic status of the family. Surprisingly, there were very few significant differences between the two socioeconomic groups based on parent reported skill level. The only two items that showed a significant difference by SES were 'keeping the home clean' and 
'how to talk to an academic advisor.' What is more interesting is that the students in the lower SES group performed better than their higher SES counterparts in these domains. Because the students from a lower SES family were perceived as better at functioning in these skill areas, these results could suggest that these students possess a greater need for independence and selfsufficiency than their high SES peers. Children from lower SES families may have more experience with keeping their homes clean due to a greater need to help out at home, and they may need to function more independently in the school system.

\section{Limitations}

There were several limitations to this study. First, data collected were via self-report, which may have impacted the accuracy of the information. Thus, there is a possibility of participant recall bias, because the parents were asked to remember their thoughts from when their children were beginning college. Data were only collected from parents, so it is unclear whether students would agree with parent perception of student functioning, or whether this reflects actual ability. Fewer than $10 \%$ of those who were offered an opportunity to participate actually participated in the study, and it is unclear whether this group differed from the entirety of the student population. When interpreting the findings, it is important to use caution, because a correction test (such as Bonferroni) cannot be used for comparison between two groups. Additionally, having multiple comparisons can lead to false positive results.

A major limitation to this study was the discrepancy in the number of participants from high and low SES backgrounds. There was an overwhelmingly large number of high SES parents who chose to answer this survey. This could be an issue of accessibility, or could reflect the demographic breakdown of this institution. Further, the categorical nature of the SES groups restricted the ability to examine the data. Because there were few respondents from lower SES families, the researchers were forced to compare "low SES" and "high SES," which does not reflect the nuances in income and other factors that lead to an individual belonging to a certain socioeconomic status.

\section{Conclusions}

This study showed significant differences in how parents view their children as functioning in many life skills based on their child's gender. However, there were very few instances in which significant differences were shown based on the family's socioeconomic status. 
There is hope that information from this study could be used to develop educational materials to appropriately target audiences to ensure a smoother transition into college. Universities can support their students by developing educational programs that help them grow in the areas they need the most help. For example, program materials should be particularly appealing to male students, who might be more likely to need training in life skills. Additionally, the positive relationship between mother expectations and student achievement, as shown by Benner and Mistry (2007), can be used as a foundation for applications in higher education. Institutions of higher education can encourage parents to display high expectations of their students, regardless of the gender or the SES of the student. Further studies are needed to investigate socioeconomic differences more thoroughly and in a more representative way. There is also work to be done to assess the needs of incoming students who do not identify with the traditional gender binary.

\section{References}

Blacksher, E. (2002) On being poor and feeling poor: Low socioeconomic status and the moral self. Theoretical Medicine and Bioethics, 23, 455-470. doi: 10.1023/A:1021381616824.

Benner, A. D., \& Mistry, R. S. (2007). Congruence of mother and teacher educational expectations and low-income youth's academic competence. Journal of Educational Psychology, 99(1), 140-153.

Bornholt, L., \& Goodnow, J. (1999). Cross-generation perceptions of academic competence: parental expectations and adolescent self-disclosure. Journal of Adolescent Research, 14 (4), 427-47.

Conley, C. S., Kirsch, A. C., Dickson, D. A., \& Bryant, F. B. (2014). Negotiating the transition to college: Developmental trajectories and gender differences in psychological functioning, cognitive-affective strategies, and social well-being. Emerging Adulthood, 2(3), 195-210. doi:10.1177/2167696814521808

Deforche, B., Van Dyck, D., Deliens, T., \& De Bourdeaudhuij, I. (2015). Changes in weight, physical activity, sedentary behavior and dietary intake during the transition to higher education: A prospective study. The International Journal of Behavioral Nutrition and Physical Activity, 12. doi:10.1186/s12966-015-0173-9

Dias, D., \& Sá, M. J. (2014). The Impact of the transition to HE: emotions, feelings and sensations. European Journal of Education, 49(2), 291-303. doi:10.1111/ejed.12058

D’Lima, G. M., Winsler, A., \& Kitsantas, A. (2014). Ethnic and gender differences in first-year college students' goal orientation, self-efficacy, and extrinsic and intrinsic motivation. Journal of Educational Research, 107(5), 341-356. doi:10.1080/00220671.2013.823366

Durand-Bush, N., McNeill, K., Harding, M., \& Dobransky, J. (2015). Investigating stress, psychological well-being, mental health functioning, and self-regulation capacity among university undergraduate students: Is this population optimally functioning? Canadian Journal of Counselling and Psychotherapy, 49(3), 253-274. 
Ellison P.A.T., \& Nelson A. (2009) Brain development: Evidence of gender differences. In E. FletcherJanzen (ed.), The Neuropsychology of Women (pp. 1-20). New York: Springer.

Holden, S.L., Pugh, S.F., Norrell, P.M., \& Keshick, C.M. (2014). Nutritional knowledge of Alabama undergraduate students. The Sport Journal, 15. Retrieved from http://thesportjournal.org/article/nutritional-knowledge-of-alabama-undergraduate-students/

Jorfi, H., Bin Yacco, H. F., \& Shah, I. M. (2012). Role of gender in emotional intelligence: relationship among emotional intelligence, communication effectiveness, and job satisfaction. International Journal of Management, 29(4), 590-597.

Klein, W., Graesch, A. P., \& Izquierdo, C. (2009). Children and chores: A mixed-methods study of children's household work in Los Angeles families. Anthropology of Work Review, 30(3), 98-109. doi:10.1111/j.1548-1417.2009.01030.x

Krishnan, S., Cozier, Y. C., Rosenberg, L., \& Palmer, J. R. (2010). Socioeconomic Status and Incidence of Type 2 Diabetes: Results From the Black Women's Health Study. American Journal of Epidemiology, 171(5), 564-570. http://doi.org/10.1093/aje/kwp443

Leedy, G. M., \& Smith, J. E. (2012). Development of emotional intelligence in first-year undergraduate students in a frontier state. College Student Journal, 46(4), 795-804.

Marks, J., Bun, L. C., \& McHale, S. M. (2009). Family patterns of gender role attitudes. Sex Roles, 61(34), 221-234. http://doi.org/10.1007/s11199-009-9619-3

Solis, O., \& Durband, D. B. (2015). Financial support and its impact on undergraduate student financial satisfaction. College Student Journal, 49(1), 93-105. 